\title{
INOVASI TEKNOLOGI BERBASIS WIRELESS DATA LOGGERLOTRE HOAX (LOG TEMPERATURE, HUMIDITY, TIME ON SD CARD AND COMPUTER) DALAM BUDIDAYA TANAMAN PADA GREENHOUSE
}

Innovation Technology Based On Wireless Data Logger Lottery Hoax (Log Temperature, Humidity, Time On Sd Card And Computer) In Plant Cultivation In Greenhouse

\author{
Trisnagani Citra Goenadi ${ }^{1}$, Ihsan Rohamat Sukuri ${ }^{2}$, Azman Fadhli $\mathrm{R}^{3}$ \\ Fakultas Teknik, Universitas Jambi \\ Jambi, Indonesia \\ trisnagani130997@gmail.com
}

\begin{abstract}
Plant cultivation in greenhouses has several obstacles, namely monitoring environmental conditions in greenhouses. Limitations of measuring instruments used to monitor environmental conditions can also affect humidity and temperature so that they can reduce the quality and quantity of crop cultivation. The design of prototype wireless data logger LOTRE HOAX based on Arduino microcontrollers and DHT11 sensors aims to monitor the process and maintain the quality of the results of crop cultivation so that it benefits farmers and industries that cultivate crops in greenhouses. The method used in this study is the observation method which includes the design of system tools, calibration of equipment, system analysis, manufacture of data acquisition design, and observation of testing. The results of testing this monitoring system proved that the DHT11 sensor works well as a detector the average error value produced is $0.15 \circ \mathrm{C}$ and $0.16 \% \mathrm{RH}$ and can answer the monitoring needs of temperature and humidity in the environment around the farm regularly with data directly stored in the SD card. Conclusions from this study that LOTRE HOAX can be in real time to analyze temperature and humidity data in the environment around the greenhouse so as to facilitate the monitoring process that becomes more efficient and faster to maximize crop cultivation results in terms of quality and quantity.
\end{abstract}

Keywords: DHT11, Greenhouse, Arduino Microcontroller, SD card, Wireless Data Logger

\begin{abstract}
Abstrak
Budidaya tanaman pada greenhouse mempunyai beberapa kendala, salah satunya pemantauan kondisi lingkungan pada greenhouse. Keterbatasan alat ukur yang digunakan untuk memantau kondisi lingkungan juga dapat mempengaruhi tingkat kelembaban dan temperatur sehingga bisa menurunkan kualitas dan kuantitas hasil budidaya tanaman.Perancanganprototype wireless data logger LOTRE HOAX berbasis mikrokontroler Arduino dansensor DHT11 bertujuan untuk pemantauan proses dan menjaga kualitas dari hasil budidaya tanaman sehingga menguntungkan para petani dan industri yang mengolah hasil budidaya tanaman pada greenhouse.Metode yang digunakan dalam penelitian ini adalah metode observasi yang meliputi perancangan sistem alat, kalibrasi alat, analisis sistem, pembuatan rancang bangun akuisisi data, serta observasi pengujian. Hasil dari pengujian sistem pemantauan ini terbukti bahwa sensor DHT11 berfungsi dengan baik sebagai pendeteksi suhu dan kelembaban dengan nilai kesalahan rata-rata yang dihasilkan yaitu $0,15^{\circ} \mathrm{C}$ dan $0,16 \% \mathrm{RH}$ dandapat menjawab kebutuhan pemantauan suhu dan kelembaban di lingkungan sekitar pertanian secara berkala dengan data yang langsung tersimpan kedalam SD card.Simpulan dari penelitian ini bahwa LOTRE HOAX dapat secara real time untuk analisis data suhu dan kelembaban di lingkungan sekitar greenhouse sehingga mempermudah proses pemantauan yang menjadi lebih efisien dan cepat untuk memaksimalkan hasil budidaya tanaman dari segi kualitas dan kuantitas.
\end{abstract}

Kata Kunci: DHT11, Greenhouse, Mikrokontroler Arduino, SD card,Wireless Data Logger,

\section{PENDAHULUAN}

Dalam meningkatkan hasil

pertanian terutama di bidang cara yang biasa dilakukan oleh para petani atau para pembudidaya tanama, contohnya dengan membudidayakan tanaman menggunakan greenhouse. Penggunaan greenhouse dalam 
budidaya tanaman merupakan salah satu cara untuk memberikan lingkungan yang lebih mendekati kondisi optimum bagi pertumbuhan tanaman. Greenhouse sebagai suatu bangunan untuk budidaya tanaman, yang memiliki struktur atap dan dinding yang bersifat tembus cahaya (Wijaya, Maulana, \& Wicaksana, 2014).

Pembudidayaan tanaman di dalam greenhouse, mempunyai beberapa kendala, salah satunya pemantauan kondisi lingkungan pada greenhouse. Keterbatasan alat ukur yang digunakan untuk memantau kondisi lingkungan juga dapat mempengaruhi tingkat kelembaban dan temperatur sehingga bisa menurunkan kualitas dan kuantitas hasil budidaya tanaman. Sehingga kita harus memantau kelembaban dan temperatur dengan prototype data logger. Pada penelitian ini dilakukan perancangan prototype wireless data logger LOTRE HOAX kelembaban dan temperatur berbasis sensor DHT11 untuk pemantauan proses dan menjaga kualitas dari hasil budidaya tanaman sehingga menguntungkan para petani dan industri yang mengolah hasil budidaya tanaman pada greenhouse.

Prototype wireless data logger LOTRE HOAX yang berbasis mikrokontroler Arduino dibangun dari tiga komponen utama, yaitu modul DS3231 RTC (pewaktu), EMS SD card (perekam), dan SD card (media penyimpanan). Kemampuan minimal selang pengukuran alat adalah 5 detik setiap data. Hasil pengukuran dianalisis dengan metode plotting curve pada program Microsoft Excel. Dengan bantuan wireless data logger dapat memaksimalkan hasil budidaya tanaman dari segi kualitas maupun kuantitasnya sehingga petani, produsen industri, dan masyarakat menjadi sejahtera dan tidak mengalami kerugian.

Dilihat dari kebutuhan tersebut peneliti mengajukan penelitian tentang perancangan prototype wireless data logger Lotre Hoax yang bertujuan untuk mengirim dan menganalisa data yang masuk melalui sensor yang dapat mempermudah dalam memantau dan merekam data pada lingkungan sekitar budidaya tanaman pada greenhouse.

\section{LANDASAN TEORI}

\section{Greenhouse}

Greenhouse sering diartikan rumah kaca karena bangunannya yang terbuat dari kaca dan tembus pandang. Pada perkembangan selanjutnya ditemukan bahan lain seperti plastik dan fiberglass sehingga penyebutannya berubah menjadi rumah tanaman. Istilah Greenhouse berasal dari kata green yang berarti hijau dan house yang berarti rumah. Oleh karena itu, Greenhouse biasa diterjemahkan sebagai rumah hijau. Fungsi Greenhouse sebagai tempat menanam tanaman agar tanaman terlindungi dari intensitas cahaya matahari yang tinggi dan curah hujan yang tinggi (Wijaya, Maulana, \& Wicaksana, 2014). 


\section{Data Logger}

Komponen ini berperan sebagai perekam dan penyimpanan berbagai macam sinyal masukan yang diperoleh dari sensor. Data logger dapat dioperasikan terpisah dari komputer yang memiliki kemampuan untuk pengambilan data sendiri sesuai pengaturan alat sehingga memungkinkan untuk digunakan pada pemantauan lingkungan dalam periode tertentu. Data logger dibangun dari 2 komponen penting, yaitu seperangkat EMS SD card (media perekam) dan SD card (media penyimpanan). Data EMS SD card akan menerima langsung data dari mikrokontroler untuk disimpan (Budiharto \& Jefri, 2007).

\section{Arduino UNO}

Mikrokontroler yang berbasis datasheet atau ATmega 328P-PU. Mikrokontroler ini mempunyai 14 pin (6 sebagai PWM, dan 6 pin masukan analog), osilator kristal $16 \mathrm{MHz}$, sambungan USB dan power jack, ICSP header, dan tombol reset. Sumber daya mikrokontroler berasal dari sambungan USB atau daya eksternal DC. Mikrokontroler ini dapat dihubungkan dengan komputer atau mikrokontroler lain dan dapat diprogram sebagai USB yang berfungsi menjadi serial converter. Memori yang dimiliki lebih besar untuk program dengan penggunaan lebih kecil untuk bootloader (Andrianto, 2016).

\section{Sensor DHT11}

DHT11 adalah sensor digital yang dapat mengukur suhu dan kelembaban udara di sekitarnya. Sensor ini sangat mudah digunakan bersama dengan Arduino. Memiliki tingkat stabilitas yang sangat baik serta fitur kalibrasi yang sangat akurat. Koefisien kalibrasi disimpan dalam OTP program memori, sehingga ketika internal sensor mendeteksi sesuatu, maka modul ini menyertakan koefisien tersebut dalam kalkulasinya. DHT11 ini termasuk sensor yang memiliki kualitas terbaik, dinilai dari respons, pembacaan data yang cepat dan kemampuan anti-interference. Ukurannya yang kecil dan dengan transmisi sinyal hingga 20 meter dengan spesifikasi: Supply Voltage $+5 \mathrm{~V}$, rentang pengukuran kelembaban dari $0-90 \%$ $\mathrm{RH} \pm 5 \% \mathrm{RH}$ error pada $0^{\circ} \sim 50{ }^{\circ} \mathrm{C} \pm 2 \%{ }^{\circ} \mathrm{C}$ error dengan spesifikasi digital interfacing sistem. Membuat produk ini cocok digunakan untuk banyak aplikasi-aplikasi pengukuran suhu dan kelembaban (Adafruit).

\section{METODE PENELITIAN}

\section{Studi Literature}

Mempelajari artikel, jurnal, makalah serta buku-buku yang terkait dengan Arduino UNO, sensor DHT11, sistem kendali dan teknologi yang mendukung dalam sistem prototype wireless data logger.

\section{Metode Pengumpulan Data}

Metode pengumpulan data yang digunakan dalam penelitian ini adalah:

a. Observasi, yaitu pengumpulan data dengan melakukan pengamatan mengenai berbagai peralatan yang meliputi perancangan sistem alat, 
kalibrasi alat, analisis sistem, pembuatan rancang bangun akuisisi data, serta observasi pengujian.

b. Penelitian, yaitu proses pengumpulan data dengan melakukan penelitian terhadap berbagai hasil pengujian alat yang hampir serupa oleh pengujian lain yang masih berkaitan dengan rancangan alat prototype LOTRE HOAX yang akan dibuat baik dari video

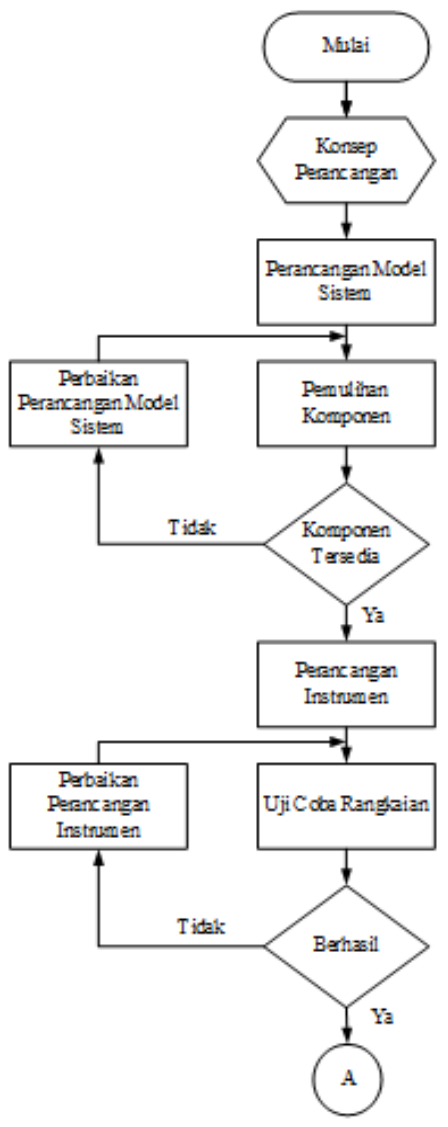

tutorial maupun melalui sumber jurnaljurnal tertentu.

\section{Perancangan Sistem}

Pada tahap ini dilakukan perancangan sistem pemantauan. Pada Gambar 1 merupakan tahapan dalam pembuatan prototype wireless data logger, suhu dan kelembaban secara real time. Hal ini dilakukan untuk memudahkan dalam perancangan dan pembuatan jurnal, sehingga dapat dilaksanakan secara sistematis.

Gambar 1. Diagram Alir Perancangan Sistem

Perancangan Perangkat Keras

Perancangan perangkat keras dibuat untuk mempermudah dalam

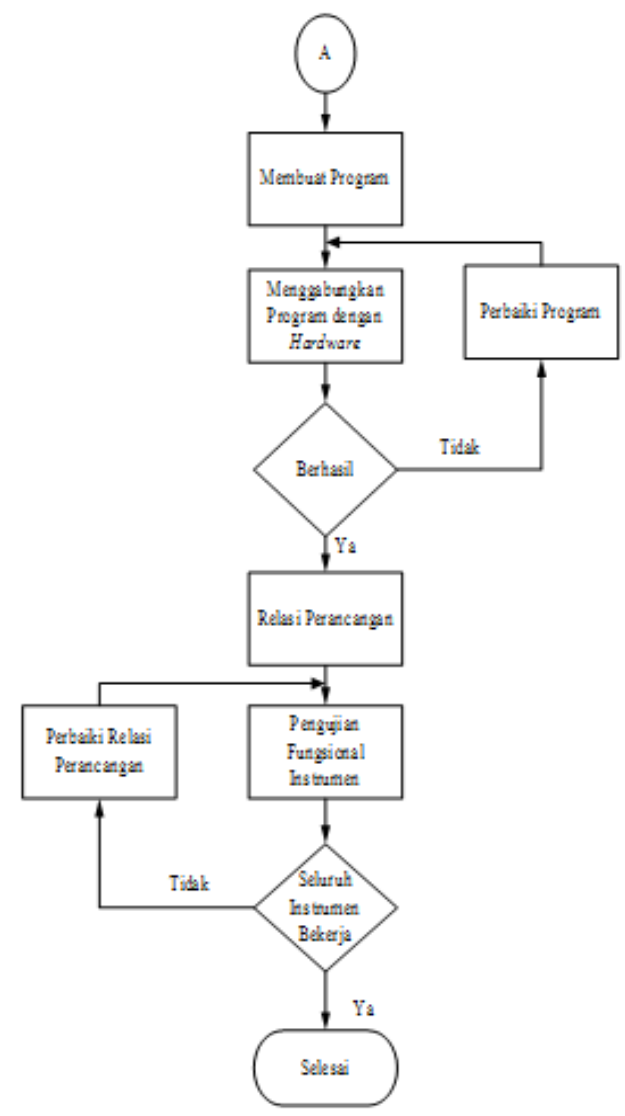

realisasi alat yang akan dibuat terlihat pada Gambar 2. 


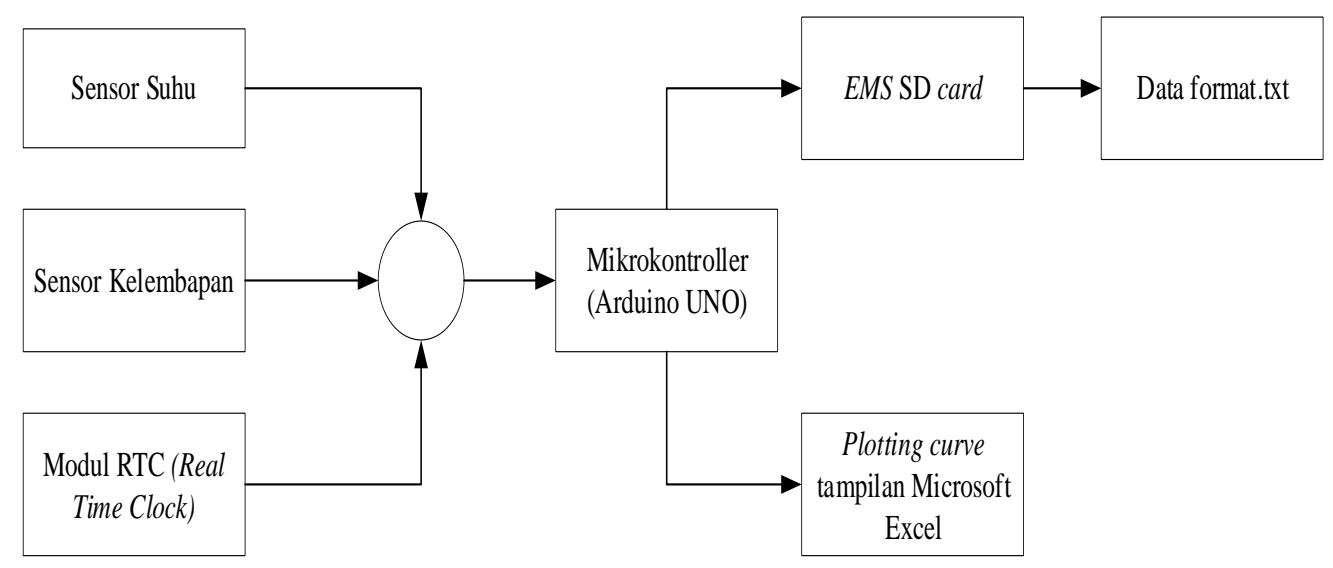

Gambar 2. Blok Diagram Perancangan Perangkat Keras

Pembuatan perangkat dimulai memperbaiki sistem. Merekam data dan setelah semua komponen tersedia, yaitu menganalisa data merupakan praktik umum di sensor suhu dan kelembaban DHT11, modul RTC DS3231, modul HC-05 dan modul SD card. Sistem yang dibangun terdiri atas pengiriman informasi berupa suhu, kelembaban, waktu. Penerima informasi yang akan diproses pada mikrokontroler Arduino UNO secara real time dan semua data akan dianalisis dengan metode plotting curve pada tampilan Microsoft Excel dan disimpan dalam SD card dalam format.txt.

\section{HASIL DAN PEMBAHASAN}

\section{Wireless Data Logger LOTRE HOAX}

Sebagai engineers/developer kami selalu mengandalkan data yang sebagian besar industri, pada penelitian ini prototype Arduino data logger akan dapat mencatat data pada interval waktu tertentu secara real time. Kami akan menggunakan Arduino untuk membaca beberapa data (suhu, kelembaban, tanggal dan waktu) serta menyimpan di kartu SD dan komputer secara bersamaan.

Data yang telah disimpan dapat dengan mudah dibuka di lembar Microsoft Excel untuk analisis lebih lanjut. Untuk mengetahui dan mempertahankan waktu dan tanggal kami menggunakan modul DS3221 RTC dan untuk mendapatkan data suhu dan kelembaban kita akan menggunakan sensor DHT11. Alat dan bahan yang dibutuhkan terlihat pada Tabel 1. dikumpulkan untuk merancang atau

Tabel 1. Daftar Tabel dan Module

\begin{tabular}{cc}
\hline Komponen & Module \\
\hline PCB layout & DHT11 module \\
Arduino UNO & SD card module \\
Connection wires & HC-05 module \\
Sdcard & DS3231 RTC module \\
\hline
\end{tabular}


Diagram sirkuit untuk prototype Temperature, Humidity, Time on SD Card and wireless data logger LOTRE HOAX (Log Computer)ditunjukkan pada Gambar 3.

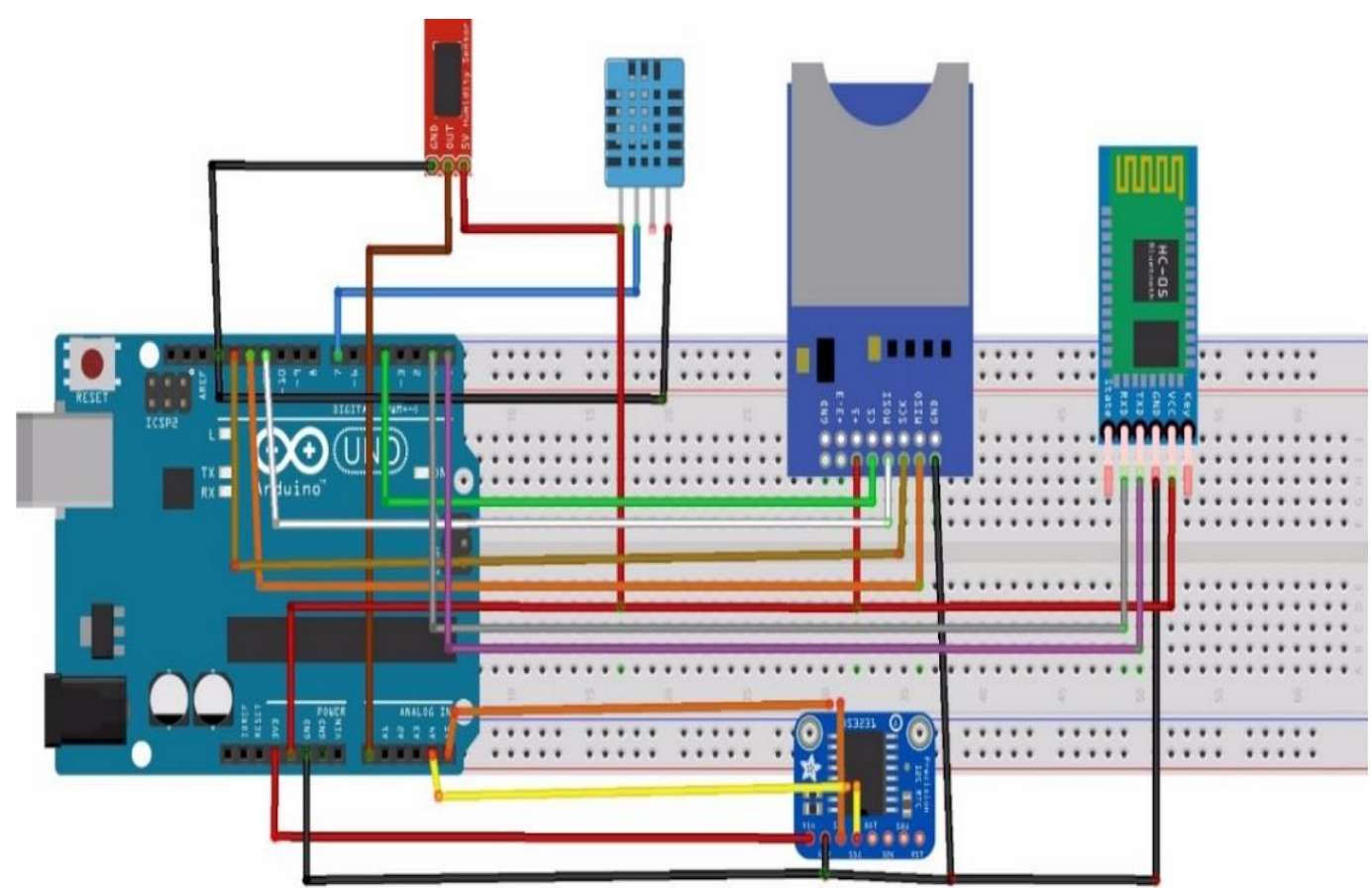

fritzing

Gambar 3. Diagram Sirkuit Prototype Wireless Data LoggerLOTRE HOAX

\section{Cara Kerja Prototype Wireless Data}

\section{Logger Arduino LOTRE HOAX}

Untuk menerima data log dari Arduino yang akan dikirim ke dalam lembar Microsoft Excel pada komputer atau laptop, menggunakan perangkat lunak PLX-DAQ yang disediakan oleh Parallax Inc. Pada perangkat lunak PLX-DAQ yang terinstal pada sistem operasi komputer/laptop, berikut tahapan-tahapan kerja Prototype WirelessData Logger Arduino LOTRE HOAX :

1. Membaca data dari DHT11 sensor

2. Inisialisasi bus I2C untuk membaca data dari modul
3. Inisialisasi bus SPI untuk menghubungkan modul kartu SD dengan Arduino

4. Menyimpan tanggal, waktu, suhu, dan kelembaban ke dalam kartu SD

5. Menyimpan tanggal, waktu, suhu dan kelembaban pada lembar Microsoft Excel yang dijalankan pada komputer atau laptop

Setelah perangkat keras dan perangkat lunak siap, saatnya untuk menjalankan program ke Arduino board. Begitu program di Upload, nilai suhu dan kelembaban akan mulai tersimpan di kartu SD. Seperti yang ditunjukkan pada Gambar 4 merupakan langkah-langkah untuk mengaktifkan PLX-DAQ untuk masuk ke lembar Microsoft Excel di komputer dan penyimpanan data logger. 


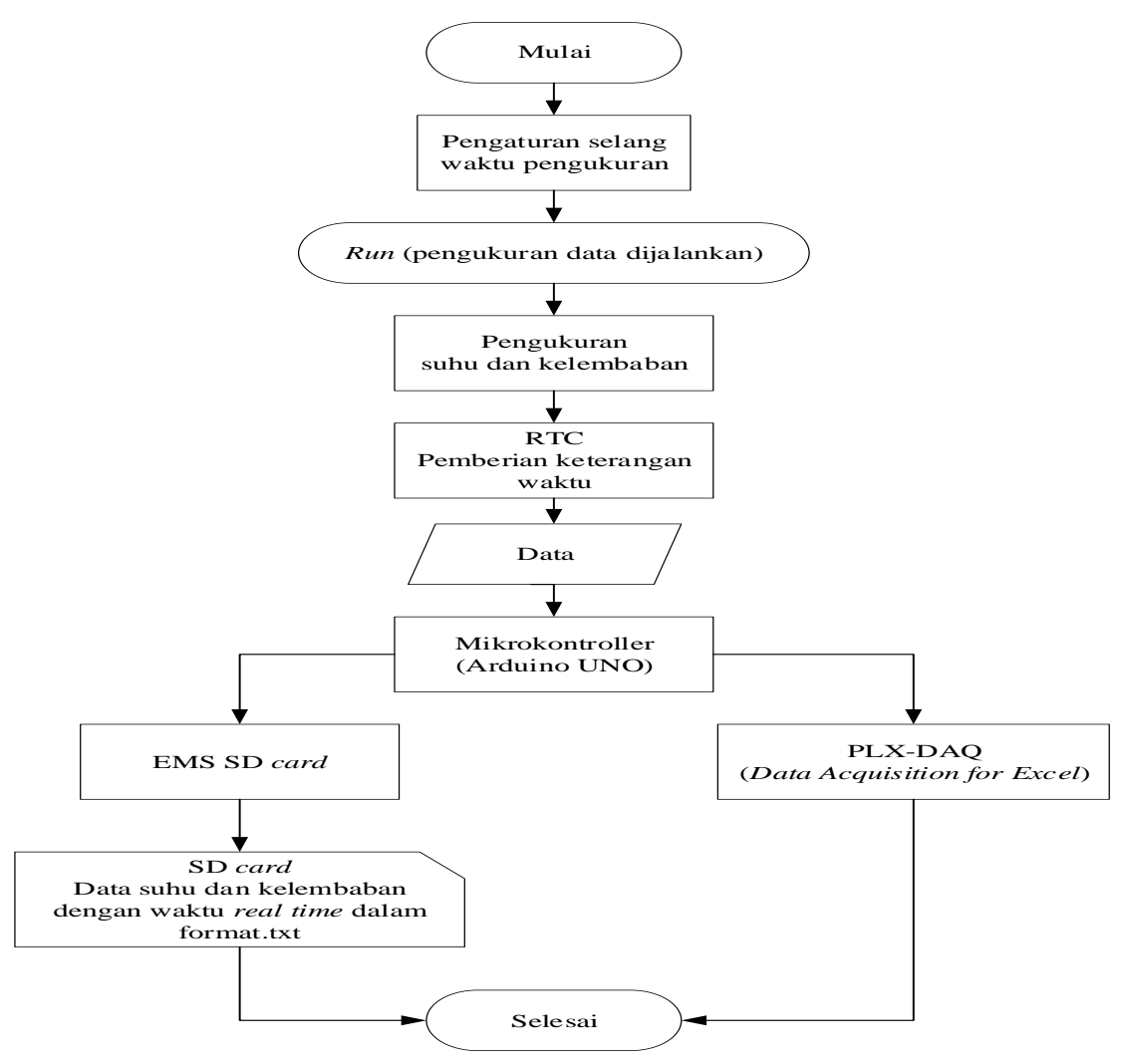

Gambar 4. Diagram Alir Tahapan Kerja Data Logger

Implementasi dan pengujian Wireless

\section{Data Logger}

Pengujian modul sensor DHT11 ini menggabungkan cara pendeteksian suhu dan kelembaban pada ruang media tanam dengan kondisi ruang tertutup. Pembacaan dari sensor DHT11 berupa keadaan suhu dengan satuan derajat celcius dan kelembaban dengan satuan \%. Nilai yang dihasilkan dari pembacaan berupa kenaikan dan penurunan keadaan suhu dan kelembaban pada ruang media tanam. Pengujian dilakukan dengan memberi tegangan 5 Volt dari mikrokontroler yang digunakan, dari pengujian ini akan diketahui mengirim data suhu dan kelembaban secara real time berbasis wireless data logger.

$$
\text { Pengujian sensor DHT11 yang }
$$
dihubungkan dengan mikrokontroler untuk pembacaan suhu dan kelembaban pada sekitar luang lingkup tanaman. Pengujian sensor DHT11 tidak bertujuan untuk mengukur akurasi pembacaan, karena output pada sensor sudah terkalibrasi.

Hasil dari pengujian sensor DHT11 dapat dilihat pada Gambar 5 dan Tabel 2 yang menunjukkan hasil observasi pembacaan sensor. Hasil dari pengujian DHT11 menunjukkan bahwa sensor dapat membaca suhu serta kelembaban serta apakah modul yang digunakan dapat dapat ditampilkan pada lembar kerja 168 |Khazanah Intelektual Volume 2 Nomor 2 Tahun 2018 
Microsoft Excel secara real time. Perubahan nilai suhu pada waktu yang berbeda menunjukkan bahwa sensor sudah bekerja dengan baik dan dapat mengetahui perubahan suhu.

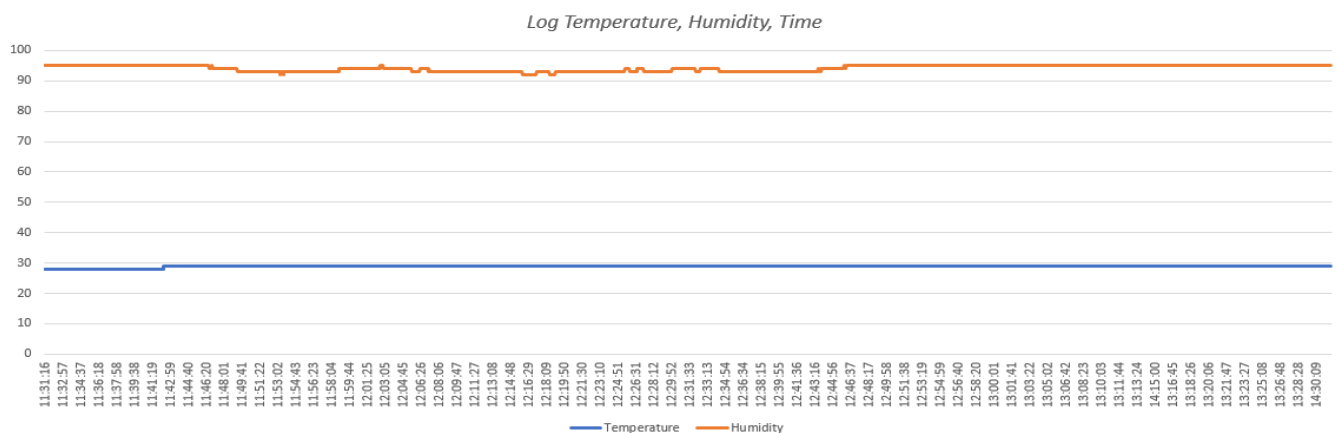

Gambar 5. Rata-rata Waktu Respons Suhu dan Kelembaban Sensor DHT11 Tabel 2. Hasil Rata-rata Pengujian Sensor DHT11

\begin{tabular}{cccc}
\hline No & Waktu (s) & Suhu $\left({ }^{\circ} \mathrm{C}\right)$ & Kelembaban $\%$ \\
\hline 1 & $06: 14: 37$ & $26{ }^{\circ} \mathrm{C}$ & $86 \%$ \\
2 & $08: 00: 06$ & $28{ }^{\circ} \mathrm{C}$ & $87 \%$ \\
3 & $11: 31: 16$ & $28{ }^{\circ} \mathrm{C}$ & $95 \%$ \\
4 & $12: 01: 25$ & $29{ }^{\circ} \mathrm{C}$ & $95 \%$ \\
5 & $14: 30: 09$ & $29{ }^{\circ} \mathrm{C}$ & $95 \%$ \\
6 & $17: 00: 00$ & $28{ }^{\circ} \mathrm{C}$ & $96 \%$ \\
7 & $20: 00: 00$ & $26{ }^{\circ} \mathrm{C}$ & $97 \%$ \\
\hline & Secara umum data yang didapat & volume udara kering pada volume yang sama.
\end{tabular}

menunjukkan hubungan berbanding terbalik antara suhu dan kelembaban, ketika suhu lingkungan naik maka kelembaban relative akan berkurang. Selain itu nilai kelembaban juga dipengaruhi oleh faktor eksternal lainnya, yaitu angin, radiasi cahaya dan aktivitas organisme. Secara matematis kelembaban dapat diartikan sebagai rasio berat uap air berbanding dengan
Pada pengujian di ruang lingkup tanaman, data kelembaban pada pukul 13:52:46 WIB sampai 14:45:31 WIB mencapai nilai 99,90\% mengindikasikan bahwa kandungan air udara tinggi. Tingginya kandungan air ini disebabkan oleh hujan yang terjadi saat itu. Namun nilai suhu yang terukur tetap bervariasi, seperti yang diperlihatkan pada Gambar 5 dan 6.

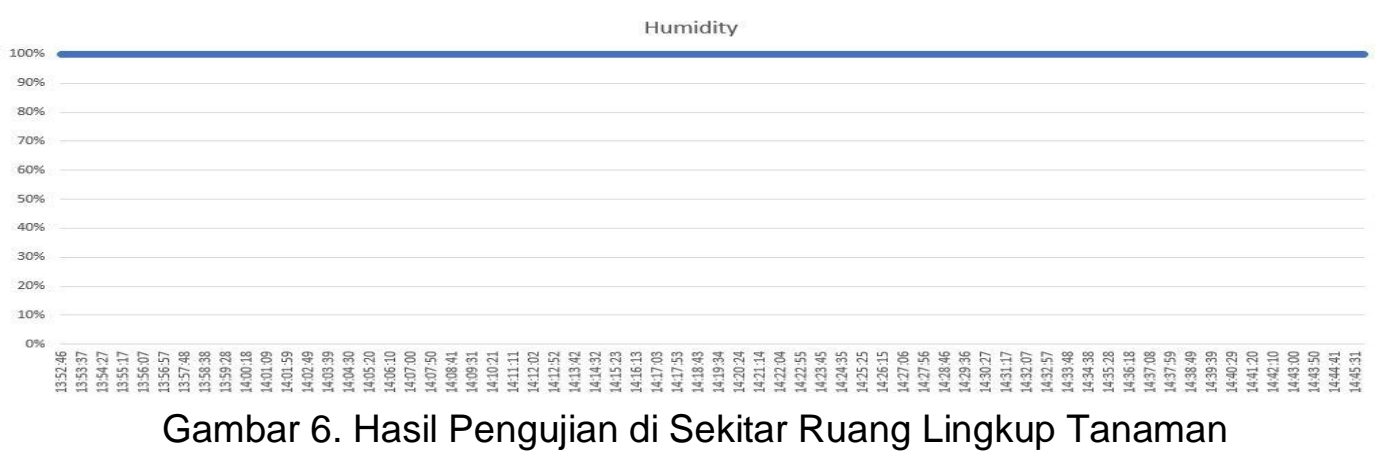

Inovasi Teknologi Berbasis Wireless Data Logger Lotre Hoax (Log Temperature, Humidity, Time On Sd Card And Computer) Dalam Budidaya Tanaman Pada Greenhouse-Trisnagani Citra Goenadi, 
Pengiriman data suhu dan kelembaban secara real time dengan wireless yang dapat terkoneksi pada PLXDAQ untuk masuk ke lembar Microsoft Excel di komputer. Data pengukuran yang langsung disimpan ke SD card dalam format.txt sehingga nantinya mudah untuk diolah ke dalam berbagai format. Secara program alat ukur ini membutuhkan waktu 5 detik untuk melakukan perekaman data dan sudah stabil pada pengukuran data per menit. Pembuatan rancang bangun alat ukur suhu dan kelembaban dapat dilakukan sesuai dengan tujuan yang dirancang.

\section{Kesimpulan}

Berdasarkan hasil perancangan prototype wireless data logger LOTRE HOAX dalam budidaya tanaman pada greenhouse dapat diambil beberapa kesimpulan sebagai berikut :

1. Pada pengujian sistem pemantauan ini terbukti bahwa sensor DHT11 berfungsi dengan baik sebagai pendeteksi suhu dan kelembaban dengan nilai kesalahan rata-rata yang dihasilkan yaitu $0,15{ }^{\circ} \mathrm{C}$ dan $0,16 \% \mathrm{RH}$, serta dapat menjawab kebutuhan pemantauan suhu dan kelembaban di lingkungan sekitar pertanian secara berkala dengan data yang langsung tersimpan kedalam SD card.

2. Parallax Data Acquisition tool (PLXDAQ) untuk Microsoft Excel yang menyediakan analisis spreadsheet data yang dikumpulkan dari lapangan secara real time untuk analisis data suhu dan kelembaban di lingkungan sekitar greenhouse sehingga mempermudah proses pemantauan yang menjadi lebih efisien dan cepat untuk memaksimalkan hasil budidaya tanaman dari segi kualitas dan kuantitas.

\section{Saran}

Saran yang dapat dilakukan untuk penelitian selanjutnya yaitu:

1. Pemilihan sensor harus diperhatikan dengan melakukan proses kalibrasi ulang agar hasil pengukuran lebih akurat dan teliti.

2. Untuk pengembangan lebih lanjut dapat dilakukan pada pembuatan variasi pengukuran suhu dengan kontrol manual.

3. Harapannya untuk sumber tegangan, alat menggunakan energi portable yang dapat diambil langsung dari alam dan ramah lingkungan seperti panel surya.

4. Diperlukannya penyempurnaan desain alat demi berbagai macam kebutuhan monitoring suhu dan kelembaban diberbagai kondisi alam.

5. Dapat dijadikan pengembangan alat otomatis berbasis wireless data logger LOTRE HOAX bersama BALITBANGDA Provinsi Jambi untuk teknologi tepat guna bagi para petani dan masyarakat pembudidaya tanaman. 


\section{DAFTAR PUSTAKA}

Adafruit. (n.d.). DHT11 Basic Temperature Humidity Sensor + Extras. Retrieved April 15, 2018, from https://www.adafruit.com/product/ 386

Andrianto, H. (2016). Arduino Belajar Cepat dan Pemrograman. Jakarta: Informatika.

B, L. (1994). Dasar Klimatologi. Jakarta: PT Ragagrafindo Persada.

Banzi, M. (2011). Getting Started with Arduino. Italy: O'Reilly Media, Inc.

Budiharto, W., \& Jefri, T. (2007). 12 Proyek Sistem Akuisisi Data. Jakarta: Elex Media Komputindo.

Ch, M. (1991). Power Electronics and Drive Technology 1. Germany: Leybold Didactic.

Elson, J. (2003). Time Synchronization for Wireless Sensor Networks. Los Angeles: University of California.
eproLabs. (n.d.). Moisture Sensor. Retrieved April 23, 2018, from https://wiki.eprolabs.com/index.ph p?title=Moisture_Sensor

Mubyarto. (2007). Pengantar Eknonomi Pertanian. Jakarta: Lembaga Penelitian, Pendidikan dan Penerangan Ekonomi \& Sosial.

Rashid, M. (1998). Power Electronics: Circuits, devices and applications. New Jersey : Prentice-Hall, Inc.

Rashid, M. (2007). Power Electronics Handbook. California: Elsevier, Inc.

Semiconductor, N. (n.d.). Retrieved April 4, 2018, from nRF24L01 Ultra low power 2.4GHz RF Transceiver IC: http://www.nordicsemi.com/eng/Pr oducts/2.4GHz-RF/nRF24L01

Wijaya, A., Maulana, A., \& Wicaksana, B. (2014). Penggunaan Greenhouse Dalam Budidaya Tanaman. Bandung: Institut Pertanian Bogor. 